\title{
Phytochemical and Proximate Analysis of Some Medicinal Leaves
}

\author{
Abiodun Bukunmi Aborisade ${ }^{1, *}$, Adewale Adetutu ${ }^{2}$, Abiodun Olusoji Owoade ${ }^{2}$ \\ ${ }^{1}$ Department of Science Laboratory Technology, Osun State College of Technology, Esa Oke, Nigeria \\ ${ }^{2}$ Department of Biochemistry, Ladoke Akintola University of Technology, Ogbomoso, Nigeria
}

Email address:

Adebisi1938@gmail.com (A. B. Aborisade), aadetutu@lautech.edu.ng (A. Adetutu), aoowoade@lautech.edu.ng (A. O. Owoade)

*Corresponding author

\section{To cite this article:}

Abiodun Bukunmi Aborisade, Adewale Adetutu, Abiodun Olusoji Owoade. Phytochemical and Proximate Analysis of Some Medicinal Leaves. Clinical Medicine Research. Vol. 6, No. 6, 2017 pp. 209-214. doi: 10.11648/j.cmr.20170606.16

Received: June 1, 2017 Accepted: July 11, 2017 Published: December 25, 2017

\begin{abstract}
The proximate analysis and the phytochemical constituents were investigated in Magnifera, Morinda lucida, Parquetina nigrescens, Oscmium gratissimum, Chenopodium ambrosioides and Veronia amygaldalina using standard reference methods. The proximate analysis in \% showed that Chenopodium ambrosioides had the highest amount of ash content of 17.30 and moisture content of 89.40 while Magnifera indica had the lowest amount of ash content 12.04 and moisture content 68.40 . Veronia amygaldalina had the highest amount of protein 30.02 and carbohydrate 54.00 while Parquetina nigrescens had the least amount of protein 25.06 and carbohydrate 40.23. Parquetina nigrescens had the highest amount of crude fibre of 25.05 while Chenopodium ambrosioides had the highest amount of crude fat 18.22 . The moisture content was found to be $89.40 \%$, ash content 17.30 , fat $18.22 \%$, protein $30.02 \%$, crude fibre $25.05 \%$ and carbohydrate $54.00 \%$. The phytochemical constituents indicated flavonoid 28.58\% alkaloid 25.84\% and tannin 2.94\% in Magnifera indica, Veronia amygaldalina and Morinda lucida respectively. The presence of high secondary metabolites in the leaves are good indication that if the plant is subjected to further research such as identification and characterization of plant, bioactive compounds with strong biological activities may be isolated and novel compounds may also be identified.
\end{abstract}

Keywords: Medicinal Leaves, Proximate Analysis, Phytochemical Analysis

\section{Introduction}

Medicinal plants are plants which contain substances that could be used for therapeutic purposes or which are precursors for the synthesis of useful drugs [46]. The medicinal value of these plants lies in bioactive phytochemical constituents that produce definite physiological action on the human body [8]. Ocimum gratissimum which belongs to the family of Lamiaceae and found mostly in the tropical countries including: Nigeria, India, North and South America, Mexico and Brazil where it is popularly known as alfavaca-cravo, alfavacao, alfavaca [14]. The local names are Efinrin, Efirin aaja, Erumaba (Yoruba), Daidoyatagida (Hausa), Esewon (Edo-Akoko), Nehonwu, Nchanwu (Igbo) and Menthesauvage (French). It is traditionally used to relief pains and also used in the treatment of rheumatism, diarrhea, high fever, convulsions, diabetes, eczema, piles and as a repellant [15]. The decoction of the stem is inhaled for the treatment of catarrh and bronchitis [26].

Vernonia amygdalina is commonly called bitter leaf because of its bitter taste. It belongs to the member of Asteraceae family and a small ever-green shrub that grows all over Africa. It is reported to be a medicinal plant for diabetes and fever [16]. Bitter herbs are reportedly good for the body as they help tone the vital organs of the body like the kidney and liver. Ethnomedically, the leaves are consumed either as a vegetable (macerated leaves in soup) or aqueous extracts as tonics for the treatment of various illnesses [29].

The roots of $V$. amygdalina have been used for gingivitis and toothache due to its proven antimicrobial activity from the previous work being done on it [2]. In North America, of the 17 species of Vernonia all have the same effective properties as a blood purifier, uterus toner and helps also in 
the prevention of atherosclerosis [22, 41]. Many herbalists and naturopathic doctors recommend aqueous extracts for their patients as treatment for anemia, nausea, diabetes, loss of appetite, dysentery and other gastro intestinal track problems. $V$. amygdalina extracts have also been reported to help suppress, delay, or kill cancerous cells [16].

Mangifera indica is commonly known as mango, they belong to the family of Anarcadiacae. It is widely used as a source of food, medicines and timber. In Nigeria, different parts of Mangifera indica (mango tree) are commonly used as herbal preparations in the treatment of tooth ache, gastrointestinal disorders, dysentery, diarrhea, gastrointestinal tract infections, respiratory and urinary tract infections [5]. It has been noted that infection of leaves and stems extract of Mangifera produce in dogs and rabbits hypotensive action [26].

Chenopodium ambrosioides Linn (Amaranthaceae), popularly known as "mastruz" and widely used in folk medicine, being considered one of the plant species with potential for use in the production chain and to generate products of interest to the Brazilian Unified Health [47]. It is an annual or perennial herbaceous plant with distinctive aroma, upright, that reaches up to $1.5 \mathrm{~m}$ high, with dark green and camphorated pubescent leaves. Several therapeutic activities are assigned to the species, such as antiinflammatory action, antifungal, antitumor, immunomodulatory, analgesic and antibacterial. The species is distinguished by its constitution rich in flavonoids, tannins and alkaloids reportedly said by Grassi [27]. Although there are studies that attribute to $C$. ambrosioides a possible toxic action, allegedly resulting from the presence of some monoterpenes ascaridole, constituent abundant in the specie [42].

The roots, stem, bark and leaves of Morinda lucida are widely used in tropical Africa due to their reputed therapeutic value in the treatment of antiinflamatory diseases and antiparasitic diseases [36], such as inflammation and malaria $[49,13]$. Phytochemical screening revealed that M. lucida contains various types of alkaloids-anthraquinones and anthraquinols [4]. In fact, Koumaglo associated the antiplasmodial activity of $M$. lucida stem bark and root to the presence of the anthraquinones digitolutein, rubiadin-1methylether and damnacanthal [38].

Parquetin nigrescens is widely used in traditional medicine as a medicinal herb. Usually small amount of Parquetin nigrescens are used as it is very toxic especially the latex, Many vital accidents have been recorded. A plant or leave decoction is taken as an enema to treat serious kidney problems, several constipation and to induce abortion. Sometimes fresh crushed leaves are taken as an emetic to treat severe constipation [31]. A plant or leave decoction or infusion, sometimes with part of other plant species, it is drunk to treat measles, intestinal worms, diarrheal, dysentery, diabetes, menstrual disorders and venereal diseases. In very small quantities, it is given to children to treat respiratory diseases [6]. A leave decoction with honey added is drunk to reduce fatigue, jaundice, stomach ulcer and anemia as a tonic. It is also taken to treat hypotension and to ease child birth. The body is washed with a leave decoction to treat general fatigue. The leaves are the common ingredient in medication to treat insanity [37].

The contribution of different species of plant parts to health status of human cannot be over emphasized. Various plants in Nigeria have served as source of, protein, fat and carbohydrates. They become important when their functions are considered in human body [3]. Most of these plants are used to cure some diseases [39]. The ability of these plants to cure human and animal diseases is as a result of the ethnopharmacological activities carried out by these plantcontaining bioactive constituents. So many medicinal plants have been used by traditional medicine practitioners in Nigeria for the treatment of different diseases. Among the various evidence revealing that medicinal and culinary herbs have some endemic species, a diet rich in fruits and vegetables and phytochemical which decrease the risk of cardiovascular diseases and some forms of cancer are of particular interest [34]. Many of these plants are underutilized. These medicinal leaves are underutilized for effective treatments of serious human ailments. This research work looks into the quantitative determination of the phytochemical and proximate constituent levels of these plants that makes them usable for curing some diseases.

\section{Materials and Methods}

\subsection{Collection of Plant Materials}

The fresh plants were collected from a local farm in Esa oke, Osun State, Nigeria. Identification and authentication of the plants was done by Prof. J. A. Ogunkunle at Department of Pure and Applied

Biology, Ladoke Akintola University of Technology, Ogbomoso, where the specimens was deposited in the herbarium.

\subsection{Processing of Plant Materials}

The fresh leaves of the following plants Morinda lucida, Parquetina nigrescens, Magnifera indica, Oscium gratissimum, Chenopodium ambrosioides and Veronia amygaldalina were air dried at $28^{\circ} \mathrm{C}$ for 30 days. They were grounded into fine powder using an electric blender and stored in a cool dry container until use.

\subsection{Quantitative Determination of Phytochemical Analysis}

\subsubsection{Determination of Tannins}

Five gram $(5 \mathrm{~g})$ of each of the ground sample was weighed into conical flask in triplicates and $100 \mathrm{ml} 2 \mathrm{M} \mathrm{HCL}$ was added. The content was boiled on a water bath for 30 minutes. The extract was cooled and filtered using Whatman No. 1 filter paper. The filtrate was taken up twice in $40 \mathrm{ml}$ each of diethylether. The ether extract was heated to dryness and weighed. The average of each sample was calculated and their percentage. 


\subsubsection{Determination of Flavonoids}

Five gram $(5 \mathrm{~g})$ of each sample was extracted with $50 \mathrm{ml}$ of $80 \%$ aqueous methanol in triplicate repeatedly at room temperature. The whole solution was filtered through Whatman filter No. 42 (125). The filtrate was then transferred into $200 \mathrm{ml}$ beaker and evaporated into dryness over a water bath, the weight of the material and the percentage quantify was calculated. The average of each sample was calculated and their percentages.

\subsubsection{Determination of Alkaloids}

Two and half gram $(2.5 \mathrm{~g})$ of each sample was weighed into $250 \mathrm{ml}$ beaker; $200 \mathrm{ml}$ of $20 \%$ acetic acid ethanol was added and allowed to stand for 4 hrs. This was then filtered and the extract was concentrated using a water bath to evaporate about a quarter of the original volume. Concentrated ammonia solution was added drop-wise to the precipitation and was completed. The entire solution was allowed to settle and the precipitation was collected by filtrate and weighed. The average of each sample was calculated and their percentage

\subsection{Proximate Analysis}

The proximate analysis of the samples for moisture, ash, fibre and fat were done by the method of AOAC (2005). The nitrogen was determined by micro-Kjeldahl method as described by Pearson (1976) the percentage Nitrogen was converted to crude protein by multiplying. All determinations were performed in triplicates.

\section{Results}

Table 1. The table shows the results of proximate analysis of six Medicinal leaves (percentage of dry samples).

\begin{tabular}{|c|c|c|c|c|c|c|}
\hline SAMPLE & $\begin{array}{l}\text { Moisture } \\
\text { Content (\%) } \\
\end{array}$ & Ash Content (\%) & $\begin{array}{l}\text { Crude Protein } \\
(\%)\end{array}$ & $\begin{array}{l}\text { Crude Fiber } \\
(\%)\end{array}$ & Crude Fat (\%) & $\begin{array}{l}\text { Carbohydrate } \\
(\%)\end{array}$ \\
\hline Oscium gratissimum & 80.80 & 14.30 & 29.01 & 22.02 & 10.20 & 50.06 \\
\hline Parquetin nigrescen & 70.01 & 12.20 & 25.06 & 22.05 & 11.30 & 36.03 \\
\hline Morinda lucida & 70.20 & 12.25 & 29.02 & 22.01 & 10.20 & 51.66 \\
\hline Veronia amgydalina & 79.20 & 17.00 & 30.02 & 15.06 & 10.05 & 54.00 \\
\hline $\begin{array}{l}\text { Chenopodium } \\
\text { ambrosiodes }\end{array}$ & 89.40 & 17.30 & 30.00 & 13.04 & 18.22 & 43.76 \\
\hline Magnifera indica & 68.40 & 12.04 & 29.00 & 19.01 & 9.56 & 40.23 \\
\hline
\end{tabular}

Table 2. The table shows the results of phytochemical analysis of six medicinal leaves.

\begin{tabular}{llll}
\hline Samples & Tannins & Alkaloids & Flavonoids \\
\hline Morinda lucida & 2.94 & 10.08 & 22.82 \\
Parquetina nigrescens & 0.64 & 9.16 & 21.76 \\
Magnifera indica & 0.38 & 4.04 & 28.58 \\
Oscium gratissimum & 2.92 & 2.68 & 14.92 \\
Chenopodium ambrosioides & 0.40 & 13.52 & 27.59 \\
Veronia amygaldalina & 1.02 & 25.84 & 19.82 \\
\hline
\end{tabular}

\section{Discussion}

The results of proximate analysis (in \%) of $V$. amygaldalina, M. lucida, O. gratissimum, C. ambrosioides, $M$. indica, $O$. gratissimum and $P$. nigrescens leaves are shown on Table 1. The leaves contained higher amount of carbohydrates content which were 54.00, 51.66, 50.6, 43.76, 40.23 and 36.03 respectively. These results are similar to that reported for $A$. sativum (57.28) [28] but are higher than that of Senna obstusfolia (23.70) [24]. It is however lower than the value reported for P. fistulosus (62.39) [28]. Carbohydrate constitutes a major class of naturally occurring organic compounds that are essential for the maintenance and sustenance of life in plants and animals and also provide raw materials for many industries [20]. The leave is a good source of carbohydrate when consumed because it meets the Recommended Dietary Allowance (RDA) values [23].

The crude protein content $(\%)$ of $V$. amygaldalina, $C$. ambrosioides, $M$. lucida, $O$. gratissimum, O. gratissimum, $M$. indica and P. nigrescens were 30.02, 30.00, 29.02, 29.01, 29.00 and 25.06 respectively. These are higher than the protein content of Telfaria occidentalis (7.00) and Momordica balsania L. (11.29) [33], but however they are in the same range with Piper guineensis (29.78) and Talinum. triangulare (31.00) [7]. However, it compared favorably with the value reported for $A$. viridus (16.41) and $S$. oleraceae (23.74) [43]. The leaves are considered as a good source of protein because it gives us more than $12 \%$ of caloritic value from protein [44].

The ash content (in \%) of $C$. ambrosioides, $V$. amygaldalina, O. gratissimum, $M$. lucida, $P$. nigrescens and $M$. indica leaves were 17.30, 17.00, 14.30, 12.25, 12.20 and 12.04 which is lower than the values reported for the leaves of A. viridus 22.84 [43], and higher in Ipomea batatas with 11.10 [10]. They are however higher than that of $A$. sativum with 4.84 [28]. The ash content is a reflection of the amount of mineral elements present in the samples; therefore, the plants contained a good amount of minerals. The moisture content (in \%) values for the leaves of $C$. ambrosioides (89.40), O. gratissimum (80.80), V. amygaldalina (79.20), M. lucida (70.20), P. nigrescens (70.01) and M. indica (68.40) were relatively high, therefore it would speed up the growth of microorganisms and life span of stored samples would be low. The moisture content of the leave is high when compared to that of Xylopia aethiopia (16.04) [1] and Acalypha hispida (11.91) [30].

The values of the crude fat (in \%) for the leaves of $C$. 
ambrosioides, P. nigrescens M. lucida, O. gratissimum, V. amygaldalina and $M$. indica were 18.22, 11.30, 10.20, 10.20, 10.05 and 9.56 respectively which were moderate in amount when compared to those of Talinum triangulare (5.09), Amarantus hybridus (4.80) [7] and Gnetum africanum (3.15) [1]. Dietary fat increases the palatability of food by absorbing and retaining flavor [10]. A diet providing $1.20 \%$ of its caloric of energy as fat is said to be deficient for human being as excess fat consumption is implicated in certain cardiovascular disorders [10].

The crude fibre values (in \%) for the leaves of $P$. nigrescens O. gratissimum, M. lucida, $M$. indica, V. amygaldalina, and $C$. ambrosioides were 22.05, 22.02, 22.01, 19.01, 15.06 and 13.04 respectively which some are high when compared to that of $A$. esculentus with 14.71 , and some are low when compare with $M$. charantia with 16.62 [28] and low when compare with $P$. thonningii 35.03 [21] but are higher than that of Gnetum africanum (4.60), M. ureans (4.00) and Parinari polyandra. The plants are good source of crude fibre when consumed because adequate intake of dietary fibre can lower the serum cholesterol level, heart disease, hypertension, constipation, diabetes and breast cancer [32].

The result of phytochemical analysis in percentages (table 2) shows that the six medicinal plants contained alkaloids, tannins and flavonoids while tannin was slightly present in M. indica and C. ambrosioides. Alkaloids has been found to have microbiocidal effect and the major anti-diarrheal effect is probably due to their effects on small intestine and antihypertensive antifungal, antiinflammatory, antifibrogenic effect [25]. However, the result of this work is similar to the findings of Awoyinka [12] who reported the presence of alkaloid in Cnidoscolus aconitifolius.

Some alkaloids are useful against HIV infection as well as intestinal infection associated with AIDS [40]. The presence of alkaloids in the six medicinal plants makes them recommendable for patient as alkaloids possess a significant pharmacological property.

Tannin is a non-toxic and can they generate physiological responses in animals that consume them [40]. Tannin can be toxic to filamentous fungi, yeast and bacterial. The presence of tannin in the medicinal plant suggests the ability of these plants to play key roles as antifungal antidiarrheal, antioxidant and antihemorrhoidal agent [11].

In this study, the leaves of $P$. nigrescens $O$. gratissimum, M. lucida, M. indica, V. amygaldalina, and C. ambrosioides contained flavonoid. It modifies the body's reaction to allergens, virus and caranogens. It has been reported to show anti-inflammatory, antifungi, antibacterial and antimicrobial activities based on the literature [18]. Akubugwo [9] reported the presence of flavonoids in A. hybridus. This perhaps justifies the already locally established function of the plant in the treatment and management of hypertension [48].

\section{Conclusion and Recommendation}

Plants have contributed immensely to the medical field. It has been the source of most drugs used for combating infections. The six plants used in this study were found to contain the important constituent needed to combat various kinds of infection in human. From the result of proximate analysis, it is quite interesting that $V$. amygaldalina has more protein content, carbohydrate and also the presence of high content of alkaloid, tannin and flavonoid from the phytochemical analysis done is an indication that if further research can be done on those samples, novel bioactive compounds can be derived from them after the identification, isolating the compounds and characterizing them using various spectroscopic techniques.

\section{References}

[1] Abolaji A. O., Adebayo A. H. and Odesanmi O. S. (2007). Nutritional qualities of three medicinal plant parts (Xylopia aethiopica, Blighia sapida and Parinari polyandra) commonly used by pregnant women in western part of Nigeria. Pakistan Journal of Nutrition 6: 665-668.

[2] Ademola I. O. and Eloff J. N. (2011). Anthelminthic activity of acetone extract and fractions of Vernonia amygdalina against Haemonchus contortus eggs and larvae. Tropical Animal Health Production. 43:521-527.

[3] Adegoke A., Fadipin G. and Kotitu A. (2006). An assessment of dietary fiber intake of selected students in the University of Ibadan, Ibadan, Nigeria, African Journal Of Biomedical Research, (3), 157-162.

[4] Adewunmi C. O. and Adesogan E. K. (1984). Anthraquinones and oruwacin from Morinda lucida as possible agents in fasciolasis and schistosomiasis control. Fitoterapia 55: 259263.

[5] Adodo A. (2002). Nature power: Revised edition. (Don Bosco Training centre, Akure).

[6] Agbor A. G. and Odetola A. A. (2005). Effect of Parquetina nigrescens on erythrocyte indices and serum electrolytes of rats following acute blood loss. Pakistan Journal of Biological Sciences 8: 527-531.

[7] Akindahunsi A. A. and Salawu S. O. (2005). Phytochemical screening and nutrient-antinutrient composition of selected tropical green vegetables. African Journal Biotechnology. 4: 497-502.

[8] Akinmoladun C., Ibukun E. O., Obuotor E. M. and Farombi E. O. (2007). Phytochemical constituent and antioxidants activity of extract from leaves Ocimum gratissimum, Science Research Essay. Volume. 2: 163-166.

[9] Akubugwo E., Obasi N. A., Chinyere G. C., and Ugobogu A. E. (2007). Nutritional and chemical value of Amaranthus hyobridus. African Journal of Biotechnology. Volume 6: 28832889.

[10] Antia B. S., Akpan E. J., Okon P. A. and Umoren I. U. (2006). Nutritive and antinutritive evaluation of sweet potatoes (Ipomoea batatas) leaves. Pakistan Journal of Nutrition 5: 166-168.

[11] Asquith T. N., and Butter L. G. (1986). Interaction of condensed tannins with selected proteins. Phytochemistry journal Volume 25:1591-1593. 
[12] Awoyinka A. O., Balogun I. O. and Ogunnowo A. A. (2007). phyochemical screening and invitro bioactivity of Cnidoscolus aconitiifolus (Euphorbiaceae). Journal of Medicinal plants Research. Volume 3: 63-65.

[13] Bello S., Oduola T., Adeosun O. G., Omisore N. O. A., Raheem G. O., and Ademosun A. A. (2009). Evaluation of antimalarial activity of various fractions of Morinda lucida leaf extract and Alstonia boonei stem bark. Global Journal of Pharmacology 3: 163-165.

[14] Brenan P. M. (1996). Flora of Tropical East Africa. East Africa Literature Bureau, Nairobi.

[15] Chit wood D. J. (2003). Phytochemical based strategies for nematodes control. Annual Review of Phytopathology. Volume 40: 221-249.

[16] Crellin J. K., Philport J. and Tommie B. (1989). A Reference Guide to Medicinal Plants: Herbal Medicine, Past and Present, Duke University Press, page. 265.

[17] Craig W. (1999). Health-promoting properties of common herbs, American Journal of Clinical Nutrition, 70 (3), 491499.

[18] Cushnie T. P. and Lamb A. J. (2005). Antimicrobial activity of flavonoids: International Journal of Antimicrobial Agents. Volume 26:343-356.

[19] Dokai P. N., Oyenuga M., Otumara A. and Ekeh F. C. (2010). Phytochemical and antioxidant nutrient constituents of Carica papaya and Parquetina nigrescens extracts. Scientific Research and Essays 5: 2201-2205.

[20] Ebun-Oluwa and Alade A. S. (2007). Nutritional Potential of Berlandier Nettle spurge (Jatropha cathatica) seed. Pakistan Journal of Nutrition, Volume 6: 345-348.

[21] Ene-Obong H. N. and Carnovale E. (1992). A comparison of the proximate, mineral and amino acid composition of some known and lesser known legumes in Nigeria. Food Chemistry 43: 169-175.

[22] Erasto P., Grierson D. S. and Afolayan A. J. (2007). Evaluation of Antioxidant activity and the fatty acid profile of the leaves of Vernonia amygdalina growing in South Africa. Food Chemistry. 104:636-642.

[23] F. N. D. (2002). Food and Nutrition Board, Institute of Medicines. National Academy of sciences. Dietary reference intake for energy, carbohydrate, fibre, fat, fatty acids, cholesterol, protein and amino acid (Micronutrients). www.nap.edu

[24] Faruq U. Z., Sanni A., and Hassan L. G. (2002). Proximate composition of sickle pod. Senna obstusfolia leaves. Nigeria Journal of Basic Applied Science. Volume 11:157-158.

[25] Ghosal S., Krishna-Prasad B. N. and Laksmi V. (1996). Antiamoebic activity of Piper longum fruits against Entamoeba histolytica in vivo. Journal of Ethnopharmacology. Volume 50:167-170.

[26] Gills L. S. (1992). Ethnomedicinal uses of plants in Nigeria. University of Benin Press, Benin City, Edo state; Nigeria. Page 65-75.

[27] Grassi L. T., Malheiros A., Meyre-Silva C., Buss Z. S., Monguilho E. D., Frode T. S., Silva KABS and Souza M. M. (2013): From popular use to pharmacological validation: A study of the anti-inflammatory, anti-nociceptive and healing effects of Chenopodium ambrosioides extract. Journal of Ethnopharmacology 145: 127-138.

[28] Hussain N. M., Muse R., Ahmad S., Ramali J., Mahmood M., Sulaiman M. R., Shukor M. Y. A., Rahman M. F. A., and Aziz K. N. K. (2009). Antifungal activity of extracts and phenolic compounds from Barringtonia racemosa L. (Lecythidaceae). African Journal of Biotechnology. Volume 8:2835-2842.

[29] Igile G. O., Olesezk W., Burda S. and Jurzysta M. (1995). Nutritional assessment of Vernonia amygdalina leaves in growing mice. Journal of Agriculture, Food Chemistry. 43:2162-2166.

[30] Iniaghe O. M., Malomo S. O. and Adebayo J. O. (2009). Proximate composition and phytochemical constituents of leaves of some Acalypha species. Pakistan Journal of Nutrition 8: 256-258.

[31] Imaga N. A., Gbenle G. O., Okochi V. I., Adenekan S., DuroEmmanuel T., Oyeniyi B., Kayode A. A., Kayode O. T. and Odetola A. A. (2009). Anti-ulcerogenic activity of two extracts of Parquetina nigrescens and their effects on mucosal antioxidants defense system on ethanol-induced ulcer in rats. Research Journal of Medicinal Plant 3: 102-108.

[32] Ishida K., Kato T., Murakami M., Watanabe M. and Watanabe M. F. (2000). Microginins, zinc metalloproteases inhibitors from the cynobacterium Microcytis aeruginosa. Tetrahedron 56: $8643-8656$

[33] Isong E. U. and Idan U. (1997). Comparatives studies on the nutritional and toxic composition of three varieties of Lieanthera Africana. Plants Food and Human Nutrition. 51:79-84.

[34] Javanmerdi J., Stushnoff C., Lockie E. and Vivanco M. (2003) Antioxidant activity and total phenolic content of Iranian Ocimum accession, Journal of Food Chemistry, (83) 547 -550.

[35] John T. (1996) Phytochemicals as evolutionary mediators of human nutritional physiology, International Journal of Pharmcology, 34 (95), 327-334.

[36] Kambu k. (1990). Elements de Phytotherapie Comparee. Plantes Medicinales Africaines. CRP, Kinshasa

[37] Kayode A. A., Kayode O. T. and Odetola A. A. 2009. Antiulcerogenic activity of two extracts of Parquetina nigrescens and their effects on mucosal antioxidants defense system on ethanol-induced ulcer in rats. Research Journal of Medicinal Plant 3: 102-108.

[38] Koumaglo K., Gbeassor M., Nikabu O., de Souza C. and Werner W. (1992). Effects of three compounds extracted from Morinda lucida on Plasmodium falciparum. Planta Medicinal journal 58: 533-553.

[39] Lawal I., Uzokwe N., Igboanugo A., Adio A., Awosan E., Nwogwugwu J., Faloye B., Olatunji B. and Adesoga A. (2010) Phytochemical, vitamin and proximate composition of Dacryodes edulis fruit at different stages of maturation, African Journal of Pharmacy and Pharmacology, 4 (1), 4-7.

[40] McDevitt J. T., Schneider D. M., Katiyar S. K. and Edlind F. S. (1996). Berberina: a candidate for the treatment of diarrhea in AIDS patients abstract. In program and Abstracts of the 36th Interscience conference on Antimicrobial Agents and Chemotherapy. American Society for Microbiology, Washington, D. C. 
[41] Nwanjo H. U. (2005). Efficacy of aqueous leaf extract of Vernonia amygdalina on plasma lipoprotein and oxidative status in diabetic rat models. Nigeria Journal of Physiological Science. 20: 30-34.

[42] Pastor J., García M., Steinbauer S., Setzer W. N., Scull R., Gille L. and Monzote L. (2015): Combinations of ascaridole, carvacrol, and caryophyllene oxide against Leishmania. Acta Tropical journal 145: 31-38.

[43] Pandey P., Mehta R. and Upadhyay R. (2013). Physicochemical and preliminary phytochemical screening of Psoralea corylifolia. Arch Applied Science Research; 5:261265.

[44] Pearson J. (1976). Determination of phytic acid and phosphorus content of biological materials. Cambridge University Press, London.

[45] Scalbert A. (1991). Antimicrobial properties of tannins. Phytochemistry journal. Volume 30:3875-3882.
[46] Sofowora E. A. (2008). Medicinal plant and traditional medicine in Africa. John Wiley and sons limited Page 1-10.

[47] Sousa Z. L., Oliveira F. F., Conceição A. O., Silva L. A. M., Rossi M. H. and Santos J. S. (2012): Biological activities of extracts from Chenopodium ambrosioides Lineu and Kielmeyera neglecta Saddi. Annual Clinical journal of Microbiology. Antimicrobiology. 11 page 20.

[48] Taiwo C. A. J, Oyedepo J., Adebayo B., Oluwadare I. and Agboto D. (2009). Nutrient content and antinutritional factor in shea butter (Butryospermum parkil) leaves. Africa journal of Biotechnology, 8: 5888-5890.

[49] Tona L., Cimanga R. K., Mesia K., Musuamba C. T., De Bruyne T., Apers S., Hernans N., Van Miert S., Pieters L., Totté J. and Vlietinck A. J. (2004). In vitro antiplasmodial activity of extracts and fractions from seven medicinal plants used in the Democratic Republic of Congo Journal of Ethnopharmacology 93: 27-32. 